\title{
EVIDENCE THAT DIGITALIS INFLUENCES CONTRACTION OF THE HEART IN MAN
}

\author{
BY ALFRED E. COHN AND HAROLD J. STEWART \\ (From the Hospital of the Rockefeller Institute for Medical Research, New York, N.Y.)
}

(Received for publication, July 9, 1924)

\section{HISTORICAL ${ }^{1}$}

Since 1785, when digitalis was first used systematically in the treatment of human disease, the criteria which have been employed in the attempt to define precisely when the drug is indicated, have undergone changes depending on those aspects of the study of the heart which were current at the time. These 140 years fall almost naturally into distinct periods. At first a belief initiated by Withering (1785) in the efficacy of digitalis as a diuretic was general and almost unquestioned. His chief indication for the exhibition of the drug is clear from this description: "Further experience convinced me, that the diuretic effects of this medicine do not at all depend upon its exciting a nausea or vomiting; but, on the contrary, that though the increased secretion of urine will frequently succeed to, or exist along with these circumstances, yet they are so far from being friendly or necessary, that I have often known the discharge of urine checked, when the doses have been imprudently urged so as to occasion sickness."

But Withering himself could make no distinction between edema due to failure of the heart and edema due to failure of the kidneys though he was well aware that it exercised "a.power over the motion of the heart;" that was naturally impossible before the days of Hope and of Bright. The ground for the belief in the efficiacy of the drug as a diuretic rested, however, securely on prolonged and detailed observation. Opinion in later years departed from this early belief on grounds which, as can be seen now, were scarcely sufficient substitutes for direct experience. Withering's observations were confirmed, and subsequently expanded by such observers as Ferriar (1799), Kinglake (1801), and Beddoes (1801) who noted that digitalis slows the pulse and strengthens it.

In addition to its action in causing diuresis, another important effect of the drug was noticed. This was described by Kreysig (1814) who concluded that digitalis must contribute something to the energy of the heart, on account of the improvement which could be seen following its use. Throughout the century this "some-

\footnotetext{
${ }^{1}$ Use has been made in the survey of excellent papers by A. W. Meyer (1912),
} A. R. Cushny (1911), and G. C. Robinson (1922). 
thing" was frequently called "energy" by which was probably meant what would now be called an increase in contractile power. Not infrequently reference was made to the effect which digitalis exerted on edema. This effect was considered as the result of its action sometimes on the vessels, sometimes on the heart as part of a general ill defined influence (Einhorn).

Meanwhile, for reasons which we have not traced, digitalis fell into discredit and disappeared from use. Corvisart (1806-1818) for instance, does not even mention the drug in any of the editions of his book. Perhaps the indiscriminate indications given for its employment as for example in tuberculosis, scarlet fever, measles and hemorrhage, alienated the respect of physicians. Hope (1839), Bouillaud (1835), and Stokes (1853), even used it as a sedative. At all events the neglect continued and reasons justifying it were supplied later by Traube (1871) and by Corrigan (1832) on the basis of the discoveries of Laennec (1821) and Hope.

These discoveries provided the background for those discussions with which clinicians were occupied for the major part of the 19th century. Laennec's contribution consisted, as is universally known, in making it possible, during life, to detect sounds arising during the heart's action; Hope in 1831 demonstrated by experiments that these sounds are caused by the motion of the valves, and so made it possible to ascertain whether their behavior was normal. He also showed that incompetence of the aortic valves resulted in regurgitant murmurs. Perhaps as a consequence of these observations, Corrigan (1832) was able to describe the disease known as aortic insufficiency. In his original paper, he discussed the action of digitalis in this affection. This he thought was twofold; first that it was a cardiac sedative, an idea which he derived from Bertin and Bouillaud (1824) and perhaps even from Withering (1785); and second, that it slowed the pulse. He expressed his views as follows: "Having laid down the plan of treatment proper to be adopted as far as it produces effects upon the system, and through it upon the heart constituting a part of the system, it now remains to examine the propriety of employing in this disease a remedy such as digitalis, which produces a specific effect upon the heart rendering its action slow and weak, and which in consequence of that effect is usually recommended in cases of heart disease in conjunction with the measures already deprecated. In inadequacy of the aortic valves the pulse generally ranges from 90 to 110 . After each contraction of the ventricle during the pause or interval of rest occurring between that contraction and the next following, a quantity of blood is regurgitating into the ventricle. The danger of the disease is in proportion to the quantity of blood that regurgitates, and the quantity that regurgitates will be large in proportion to the degree of inadequacy of the valves, and to the length of pause between the contractions of the ventricle during which the blood can be pouring back. If the action of the heart be rendered very slow, the pause after each contraction will be long, and consequently the regurgitation of blood must be considerable. Frequent action of the heart, on the contrary, makes the pause after each contraction short; and in proportion as 
the pauses are shortened, the regurgitation must be lessened. Instead, then, of regarding an increase of frequency in the action of the heart as an aggravation of the disease, it must be viewed, as we have already viewed hypertrophy of the heart, as a provision for remedying as far as possible the evil consequences arising from inadequate valves. To retard in such circumstances the action of the heart would be to do an injury. In every case of this disease in which digitalis has been administered, it has invariably aggravated the patient's sufferings."

This statement by Corrigan set the fashion for subsequent speculation. From then until now there has been continuous discussion as to the indication for giving digitalis when the heart valves are diseased. It is interesting to notice that in this first paper on aortic insufficiency, the harm which digitalis can do in the condition, was recognized and vigorous objection to its use was taken.

The general discredit into which digitalis fell continued until about 1840. Then it began again to be used in the treatment of heart disease in Germany by Schoenlein (1842) and Traube, and in France by Aran (1842). In England, distrust of the drug continued. Stokes (1853), Latham (1847), Walshe (1854) and Fothergill (1871) followed Corrigan's view. Diagnosis based on deductions drawn from auscultation accordingly dominated the discussion. The factors which were considered to be determining were its effect on the rate of the pulse and its effect on the "energy" of the heart. There was general belief in its relative advantage in stenoses; its disadvantages in insufficiencies; its beneficial employment in mitral regurgitation, its harmfulness in aortic insufficiency. So far as the effect on the pulse rate is concerned, it was clear that no harm could be done when the mitral valves were involved; injury resulted only when insufficiency of the aortic valves existed. This discussion is, quite properly, not yet ended. Valvular disease was in 1912 still made the basis, at least in part, for deciding on the administration of digitalis in Krehl's clinic (A. W. Meyer, 1912).

It must have been Traube (1861) who furthered the view, as a result of his studies on the stimulating action of digitalis on the vagus nerves, that digitalis, because it slowed the heart, was sedative and accomplished its effects by quieting the heart. ${ }^{2}$ Whether giving digitalis increased or diminished the "energy" of the heart, became then a second matter for discussion. Fothergill (1871), Nothnagel (1878), Leyden (1881), Fränkel (1882) and Balfour (1898) in part, advocated its use, on the ground that it had this action irrespective of the presence of any valvular lesion whatsoever.

It is profitless to attempt to trace, through the writings of the distinguished clinicians of the century, the precise position which each in turn held in respect to these problems. The criteria that were available were based on auscultation, on pulse rate, and on diuresis. The effect of digitalis on rhythm, blood pressure and the size of the heart could naturally not be estimated. The chief factor in making a decision was preëminently the state of the valvular lesion,

2 This inference was in all probability drawn from the study of cases which were the subject of auricular fibrillation. 
and to a less extent, because it could be so inadequately estimated, the condition of the muscle; other factors were the pulse rate, diuresis, and, when present, such symptoms as palpitation and irregularity; ${ }^{3}$ and finally, eventualities such as are contingent on the state of the cerebral vessels and their ability to bear increased pressure. That the blood pressure was raised by digitalis physicians believed, because this effect was observed in experiments on animals.

An important new development occurred when Boehm (1872) emphasized the specific effect of digitalis on heart muscle in frogs. Traube, in all probability, as Cushny points out, missed this action because he utilized only mammals in his experiments. In frogs, however, both Boehm and Schmiedeberg easily recognized this action. The actual effects on contraction were discovered in later experiments especially those of Roy and Adami (1892), and of Cushny (1897).

The influence of this teaching became apparent almost at once in works on clinical medicine. ${ }^{4}$ It is apparent in the writings of B. Bramwell (1884) and of G. A. Gibson (1898), who applied the results of experiments directly to phenomena observed in man, without attempting to notice whether the experimental data paralleled the events in human physiology (p. 280). A more critical, almost contemporary attitude, was taken by Balfour (1898) (p. $104 \mathrm{ff}$.). At the turn of the 19th century, the way was thus paved by Krehl (1901) and Romberg (1906), for a study of the significance of the behavior of muscle in heart disease, and likewise of the effect of digitalis upon the heart muscle under clinical conditions.

That the data obtained by pharmacologists were not applicable directly to human conditions was clear from the fact that the blood pressure does not rise in human beings when they are under the influence of digitalis. Both Gottlieb and Sahli admitted this fact at the German Medical Society in 1901. But although, at that time, the blood pressure in patients could be satisfactorily measured, no method was available for studying the effect of digitalis on the heart muscle itself. It was assumed then, and also later, on the basis of such experiments as those of Jonescu and Loewi (1908), of Kasztan (1910) Fahrenkamp (1911), Gottlieb and Magnus (1902), and Joseph (1913) that, although no influence on the general blood pressure resulted from peripheral effects, such as the dilator action of the drug on the kidneys, and its constrictor action on the intestine, the efficacy of the drug was to be explained, nevertheless, through some such remote actions rather than from an influence on heart muscle. On peripheral vessels in man, Vagt (1909) and Eychmüller (1909) found no effect. And so the matter stands.

Meanwhile, stimulated by the researches of Gaskell and Engelman on the differentiation of the properties of heart muscle, a great step forward was initiated in 1902 by the work of Mackenzie and Wenckebach. The striking effect which digitalis was found to have in reducing the rate of the completely irregular pulse of auricular fibrillation, together with studies of the effect of the drug on other

\footnotetext{
${ }^{3}$ The precise mechanism was of course not diagnosticated.

${ }^{4} \mathrm{G}$. W. Balfour, Clinical Lectures on Diseases of the Heart and Aorta, 1st edition, 1875.
} 
forms of irregular heart action, deflected attention away from investigations which seemed in 1901 about to be carried forward. So great was the interest in the effect of digitalis on the cardiac irregularities, that the view arose that it was preëminently the irregular heart on which digitalis acted (Mackenzie, 1911). That it was especially indicated under these circumstances seems to have been clear to Jürgensen (1899). This belief was enforced by the observation that when the mechanism of the heart was normal, no influence on the rate was to be observed (Cohn 1915 a), except in heart failure when edema was present, or in what has come to be known as the hypodynamic heart (Cohn, $1915 \mathrm{a}$ ).

Attention was again directed to the action of digitalis on human heart muscle when evidence was obtained in electrocardiograms that changes in the curves followed on taking the drug (Cohn,1915b). These changes, which consisted in alterations in the form of the T-wave, could, so far as knowledge of the genesis of action currents is concerned, have arisen only through action on the muscle. This was the evidence in 1913 from which an effect on the human heart muscle could most directly be inferred. So strong is the belief in the inefficacy of digitalis, except in irregular heart action, that it has seemed wise actually to call attention to the fact that giving the drug aids in eliminating edema when the rhythm is regular.

The state of knowledge then, so far as human physiology is concerned, may be described in this fashion. Digitalis is known to act in man on the centers of the vagus nerves. It is known likewise that digitalis does not raise the general blood pressure. It is assumed on the basis of Cushny's (1897) observation on mammals that an effect on contraction of the heart muscle takes place in man, as it was observed in his experiments on mammals which were performed with moderate though not exactly known doses of the drug. This assumption is also held on the basis of such experiments on mammals as those of de Heer (1912), with doses far greater than those used in patients, and as the result of the analysis by Lewis, Drury and Iliescu (1922), of the effect of strophanthin on the mechanism of the contractile act, in the course of which they found that a "widening in the refractory period" took place. It is assumed that edema fluid is eliminated on the basis of such experiments as those of Joseph (1913), in which the dose given was comparable presumably with that employed in the clinic.

But so far no studies have been made directly on the effect of digitalis on the contraction of the heart muscle in man. Such investigations are here reported. 


\section{METHOD}

In attempting this investigation two methods were open to us. The first consisted in making $\mathrm{x}$-ray photographs in rapid succession of the whole heart, and recording the changes in size as the heart moves from the diastolic to the systolic position (Groedel (1909) and Dessauer (1912)). This method was developed first. Eyster and Meek (1920) extended its use. They obtained radiographs of the human heart at known instants in the cardiac cycle, by recording on electrocardiograms the time at which the radiographs were taken. From data so obtained, they calculated by the use of Bardeen's (1918) formula the volume of the heart in systole and diastole, and from the differences between these two measurements obtained the volume output of the heart per beat.

The second method introduced by Gött and Rosenthal (1912)5 consisted in photographing, with Roentgen rays, the excursion of points of the two borders of the heart. By this procedure continuous curves were obtained. Becker (1914) and Crane (1916) each made use of an apparatus similar in principle and recommended its use particularly in the study of irregularities.

The apparatus we employed resembles that of Gött and Rosenthal (figs. 1 and 2). We selected this method, first because of its greater simplicity and the greater ease with which the requisite apparatus could be constructed; secondly, because of the ease of obtainin the records; thirdly, because the records are in the form of curves which can easily be obtained in long strips throughout a whole respiratory cycle; and fourthly, because the curves obtained represent the shortening or contraction undergone during systole by that portion of the left ventricular margin that is photographed, this being exactly the effect of digitalis that concerns us. The fact that it was not possible to calculate the volume output of the heart from the measurements we obtained of the curves, did not seem to us to be a disadvantage; for the figure obtained for the volume output calculated from Bardeen's formula from data based on radiographs are said to

5 These authors call attention to the description in Polish by Sabat of an apparatus like theirs. Their own was however developed independently and without knowledge of that of Sabat. 
be accurate only within 10 per cent. Since this is about the increase in output we anticipated as the result of administering digitalis, the advantage of the method is naturally lost.

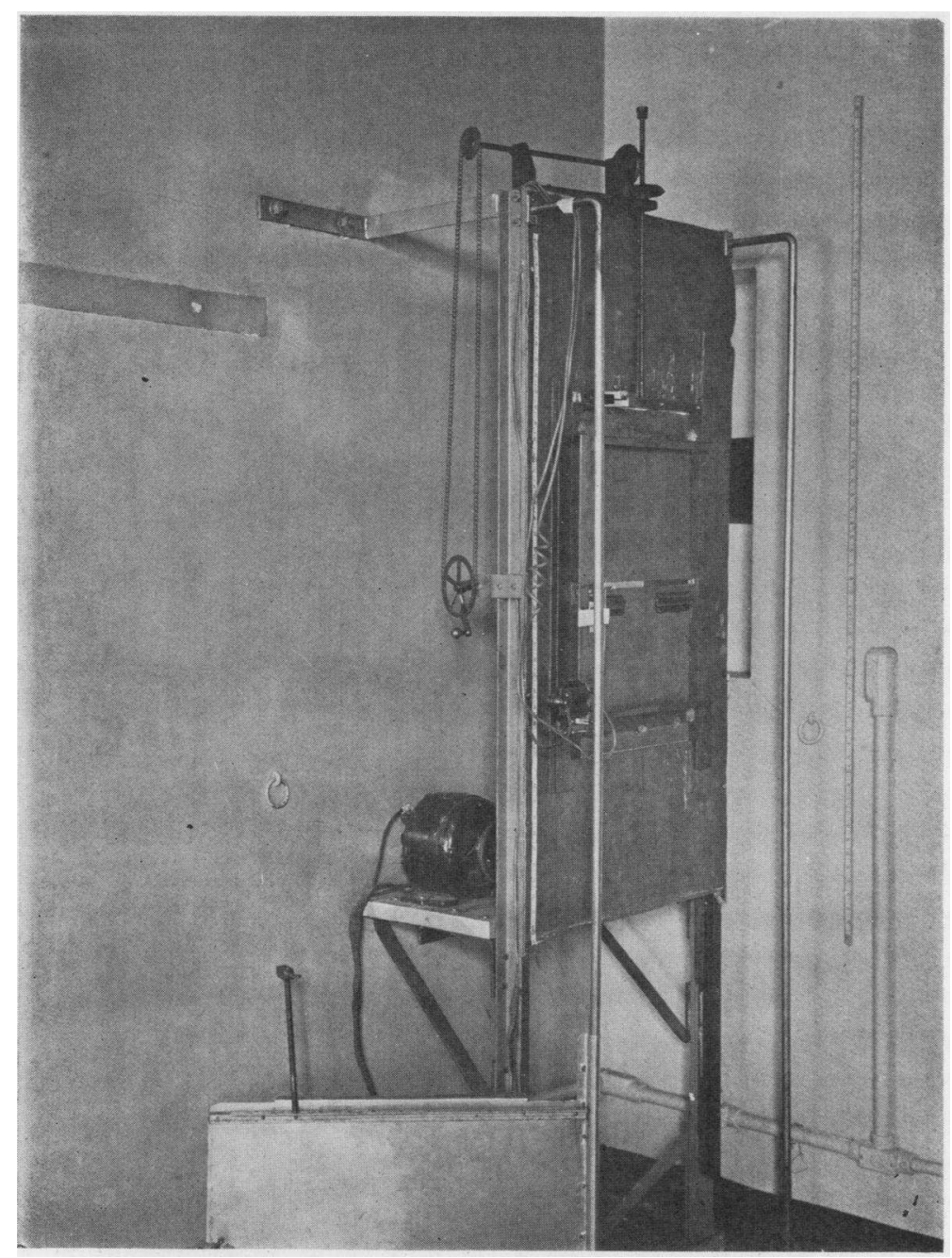

Fig. 1. Photograpil of the Apparatis Used in Making Moving X-Ray Photographs of the Heart.

See text for description of parts and figure 2 for a diagrammatic sketch of the apparatus. 
In practice $e^{6}$ the patient faces a lead screen in which a transverse slit 0.5 or $1 \mathrm{~cm}$. wide is cut. The level of the slit is adjustable. It is usually placed opposite that portion of the border of the left ventricle which exhibits the greatest excursion. The $x$-ray tube is placed behind the patient 36 inches from the lead screen. On the other side of the lead screen a cassette, which carries an x-ray film, is raised by a motor past the slit. Between the patient and the lead

Diagram of X-Ray Apparatus.

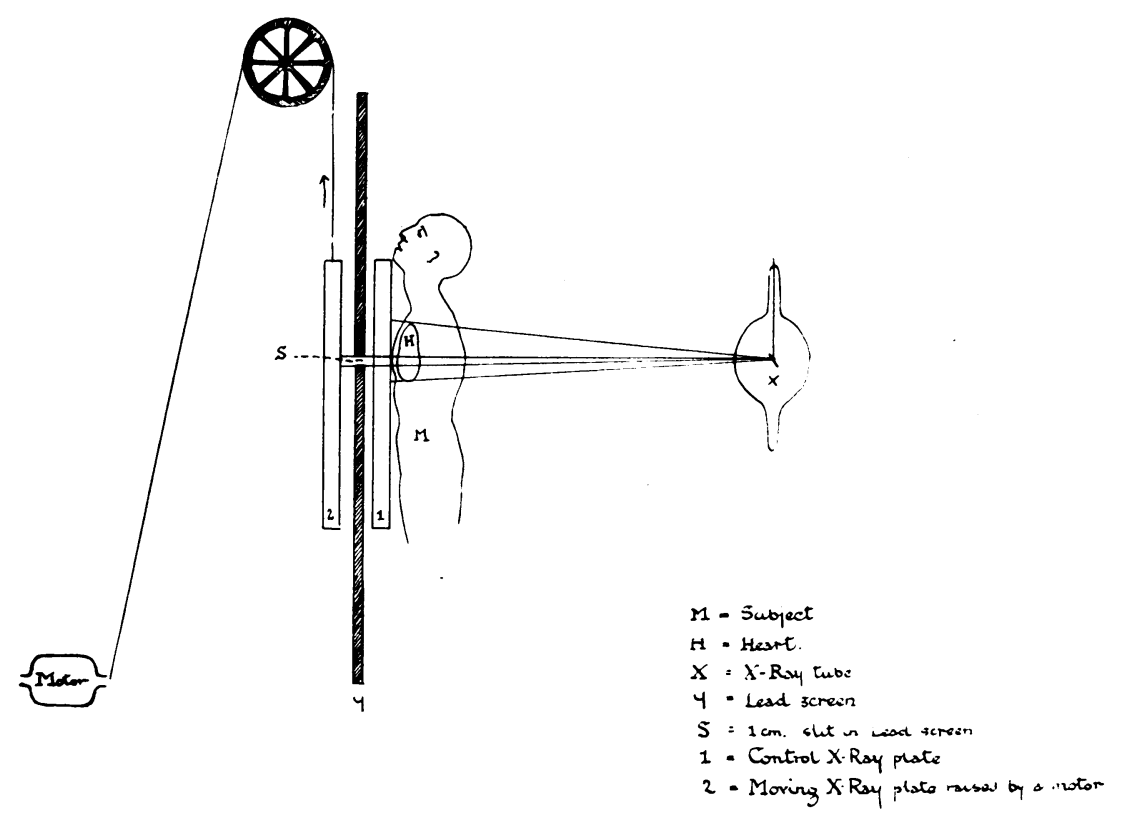

Fig. 2. Schematic Drawing of the X-Ray Apparatus Illustrating the Method of Exposing the X-RAy Films

screen another cassette is placed, which also holds an x-ray film. This is the control film and is stationary. On this it is possible, by a device next to be explained, to record the portion of the border of the heart of which the curve is made. This portion is identified by the shadows cast by two levers, which swing at the level of the slit between the patient and the stationary film. One lever records the

${ }^{6}$ The authors are deeply indebted to Miss Christine Macdonald of the x-ray Department of the Institute for her technical cooperation in this investigation. 
time in seconds; the other the respiration. The time recorder is the armature of a magnet in series with a Petzold clock. The respiratory movements are communicated to the lever of a piston-recorder by a Politzer bag bound against the chest by a muslin binder. (See figs. 1 and 2.)

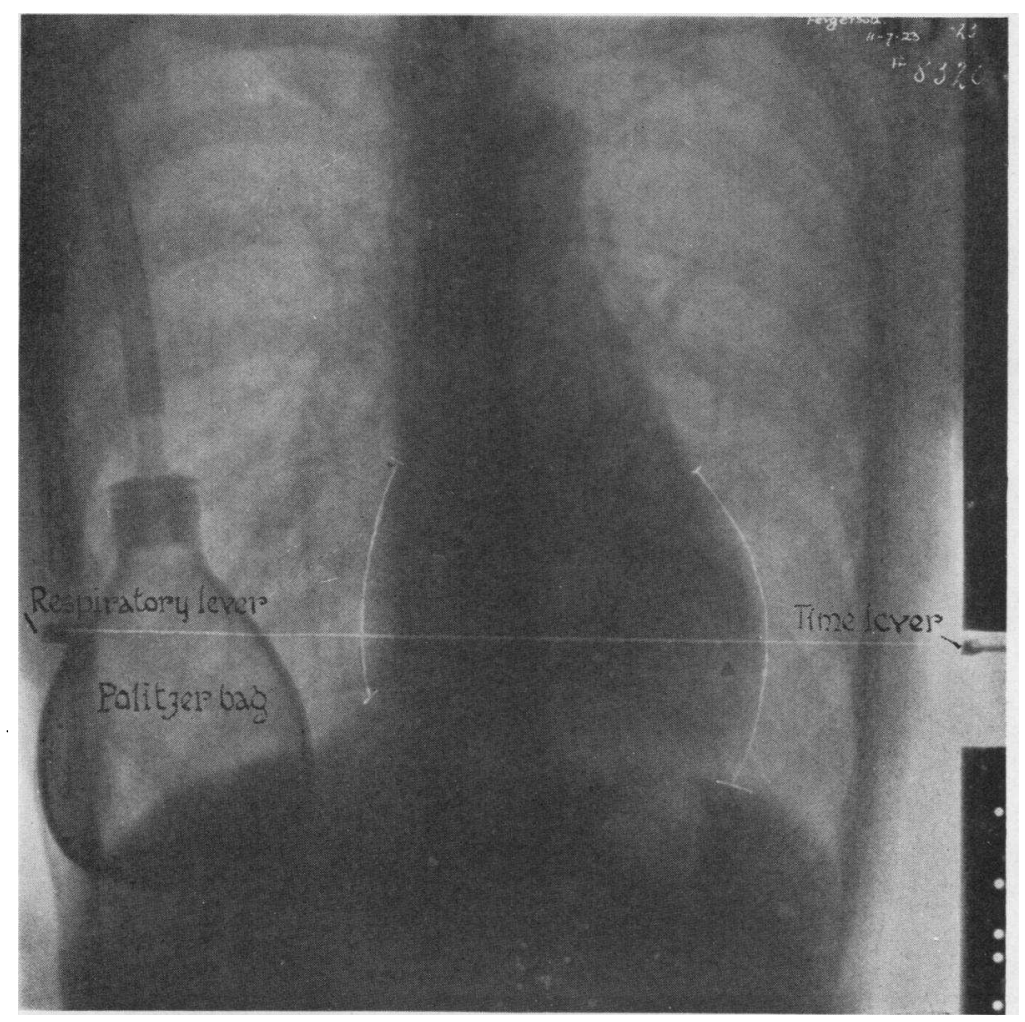

Fig. 3. Control Plate Showing Level of the Right Auricular, and of the Left Ventricular Margins of Which the Moving X-Ray Films Were Obtained

The control film was made first (fig. 3). Then without changing the patient's position the moving film was exposed. ${ }^{7}$ The records are similar to a sine-curve, the trough representing systole and the crest diastole (fig. 4). The distance between the two positions was used as a measure of the degree of ventricular contraction or shorten-

${ }^{7}$ Eastman duplitized films were used in a Reenforced French Cassette. 
ing. No attempt, as has been said, was made to infer volume changes from this simple linear measurement. The films were exposed during normal quiet breathing. Only those films were measured in which it was clear, from the controls, that identical points of the heart's margin had been photographed. That the points were identical was shown by actual superposition of the control films, as well as by comparison of the measurements made of them. The measurements were not corrected to obtain values comparable with those taken at a distance of 2 meters; the conclusions which we draw are independent of the magnification caused by the divergence of the $\mathrm{x}$-rays. We appreciate the fact that an error might result if the size, that is to say the transverse diameter, of the heart decreased after giving digitalis. In this case, the greater the decrease, the less will be the magnification of the excursion. If we correct our results in accordance with this error, we increase the magnitude of the change we found. Measurements were taken of the control film; of the original curve (moving film), and of a tracing made of the moving film. All the waves in a respiratory cycle were measured and the average of these was used.

\section{OBSERVATIONS}

In order to obtain satisfactory curves, we found it advantageous to limit the choice of patients to men, and especially men whose chests were reasonably thin. We found it desirable, also, to select men who were free from edema. This precaution we took because of the uncertainty which still prevails on the subject of the blood volume, even if this can be measured accurately, when fluid is shifted in the body from the tissues to the blood and from the blood to the urine. It was somewhat difficult to obtain suitable patients. For this reason a large series of cases is not available on which to base the subsequent study. The care with which the patients were selected, and the accuracy with which the observations were made, justify us, we think, in presenting the results of our study. We studied the curves of 5 patients. To 4

Fig. 4. Moving X-Ray Fit.m

The manner in which records like this were obtained is described in the text. (a) was taken 2-14-24, before, (b) was taken 2-18-24, after the administration of digitalis $1.2 \mathrm{gm}$., and (c) was taken 2-28-24, after the effect had worn off. 


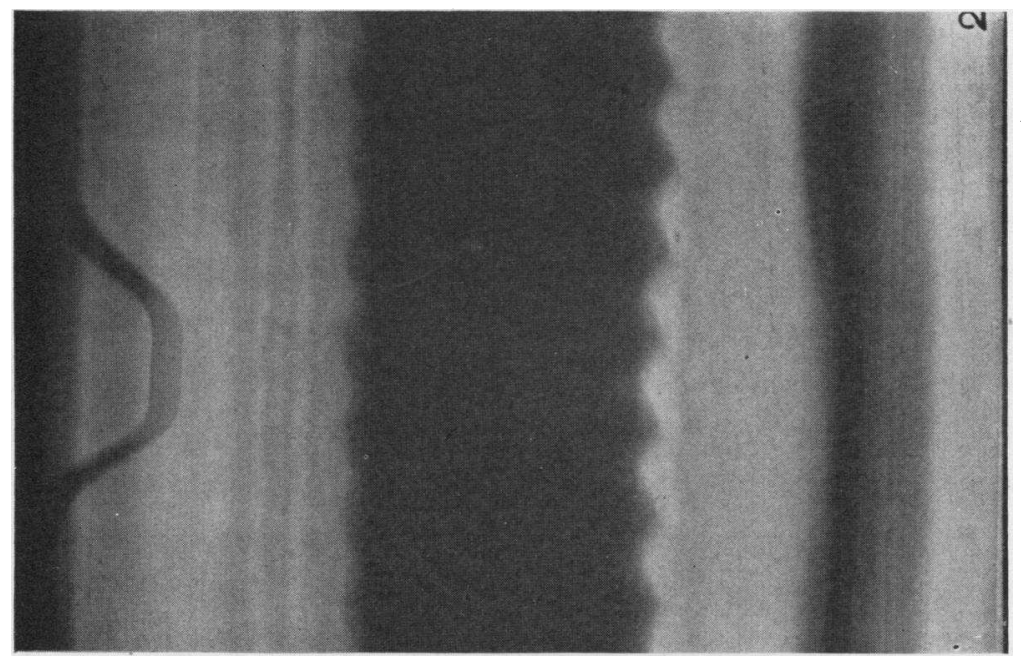

FIG. 4a

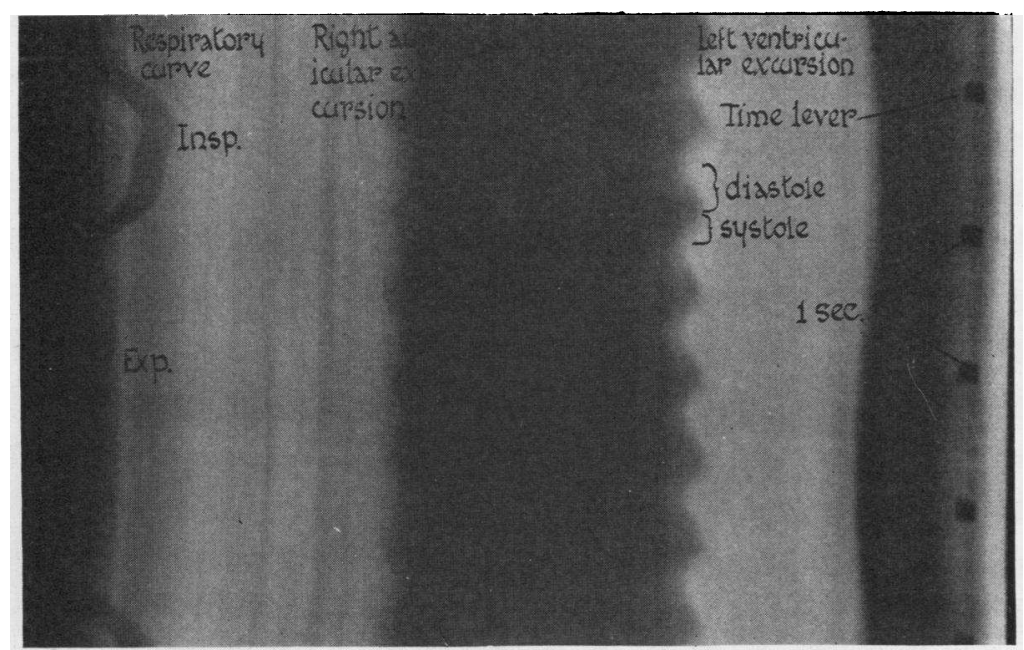

Fig. 4b

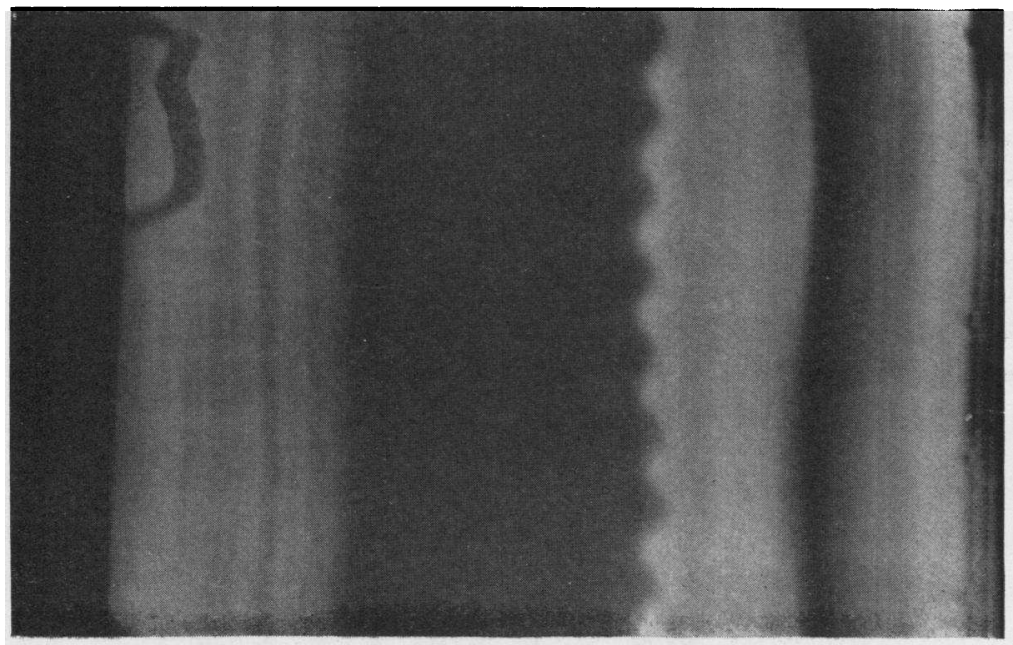

FIg. 4c

107 
digitalis was given; one served as a control. The hearts of two patients exhibited the normal rhythm; the hearts of the other two. were the subjects of auricular fibrillation. Curves were, of course, taken both before digitalis was given and again after an amount had been given sufficient to produce a therapeutic effect clinically, and to bring about changes in the $\mathrm{T}$-wave in the electrocardiogram. In three patients the observations were repeated.

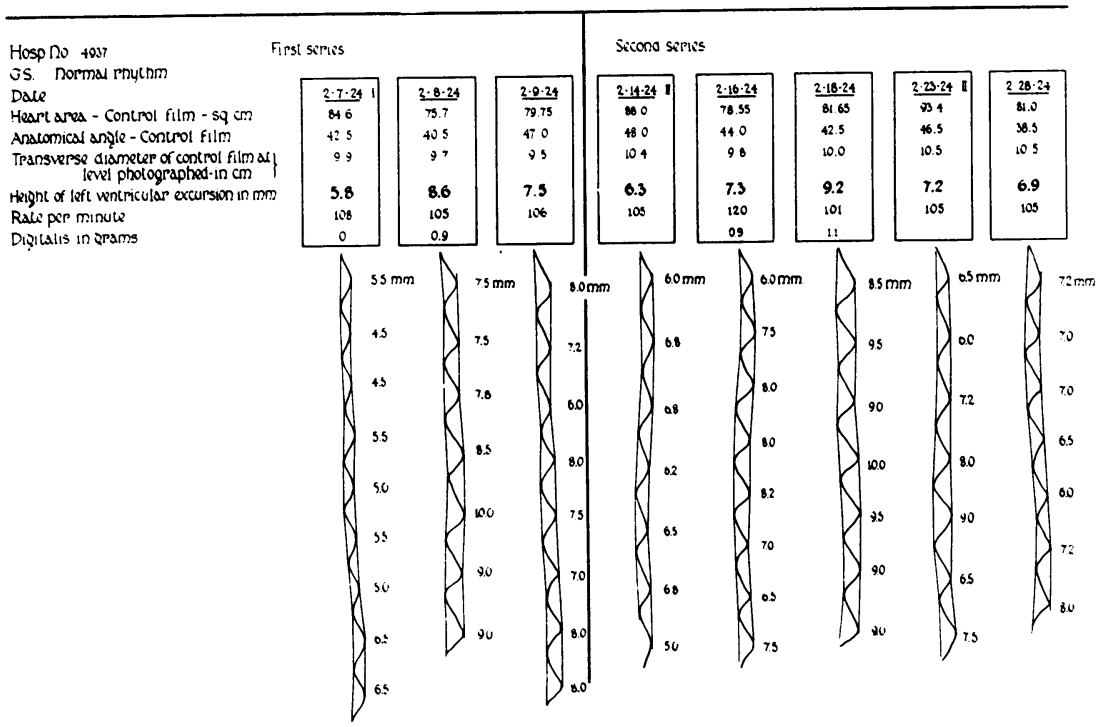

Fig. 5. In this figure and in figures 6, 8 and 9, the curves illustrated are tr..cings of the left ventricular excursion made from the original films as described in the text. At the head of each curve, in the oblong box are given measurements corresponding to the curves below.

Case 1. G. S., Hosp. No. 4937, was a male, 24 years old. He complained of "heavy beating" of his heart for 5 years and of "asthmatic" attacks for 4 years. He had influenza 5 years ago, followed by dyspnea on exertion and palpitation. The action of the heart was said to be irregular so that he was given digitalis. Four years ago he had an attack of bronchitis which later changed character and became "asthmatic."

On physical examination his heart was small and of the pendular form. There were no murmurs. There were numerous auricular premature contractions. The lungs appeared to be normal. The blood pressure was 100-122 systolic and 70-84 diastolic. There was no edema. The Wassermann reaction was negative. 


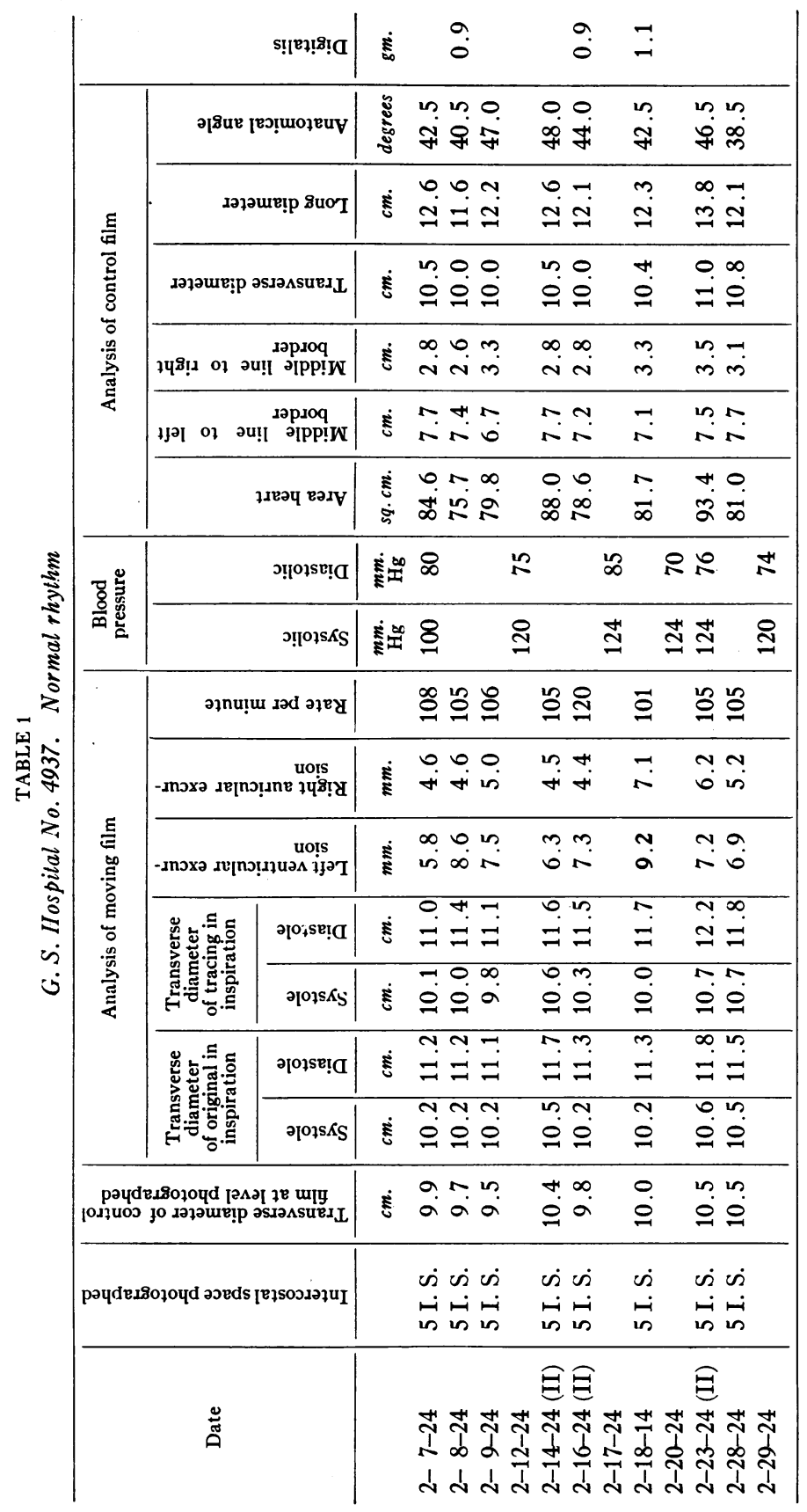


The urine was normal. At first, unusual slowing followed the administration of digitalis $(0.9 \mathrm{gm}$.$) , and the number of auricular premature contractions which had$ been present decreased. He experienced no attacks of asthma while in the hospital and none since leaving; he was moved away from his home where there were cats and dogs. It was these which caused the attacks of asthma.

On February 7, 1924, the left ventricular excursion in this patient was $5.8 \mathrm{~mm}$. in the 5 th interspace (table 1, figs. 4 and 5). On February 8 , after giving digitalis $0.9 \mathrm{gm}$., the excursion increased to $8.6 \mathrm{~mm}$. and on February 9, fell to $7.5 \mathrm{~mm}$., the rate remaining unchanged during these three observations. On February 14, in a second series of observations before giving digitalis the excursion measured $6.3 \mathrm{~mm}$. On February 16, after taking digitalis $0.9 \mathrm{gm}$., the excursion increased to $7.3 \mathrm{~mm}$., but later, on February 18 , after a total of $1.1 \mathrm{gm}$. had been given, the excursion increased still farther to $9.2 \mathrm{~mm}$. At this time a marked change in the $\mathrm{T}$-waves of the electrocardiogram was observed. The administration of digitalis was discontinued on February 18; on February 23, the excursion decreased to $7.2 \mathrm{~mm}$. and on February 28 , to $6.9 \mathrm{~mm}$. No significant changes occurred either in heart rate or in blood pressure which need be considered in accounting for the difference in the heights of the excursions observed.

Case 2. A. F., Hosp. No. 4814, was a male, 34 years old. He complained of nervousness, fatigue and palpitation for 6 months. He had suffered from scarlet fever in childhood and influenza in 1918. He passed the army tests, but was told that he had a "little" albumen in the urine.

On physical examination the heart was found to be enlarged; a late systolic murmur was heard at the apex. The rhythm was regular. The blood pressure was 160-180 systolic and 90-100 diastolic. There was no edema. The phenolsulphonephthalein test was 45 and the Van Slyke index, 27. The urine contained a small amount of albumen, red blood cells and casts. He could excrete water but was unable to concentrate the urine. The diagnosis was thought to be chronic glomerulonephritis.

Curves taken on October 5 and 11, at the level of the 5th interspace show excursions of $4.2 \mathrm{~mm}$. and $3.7 \mathrm{~mm}$. respectively (table 2, fig. 6); the difference $(0.5 \mathrm{~mm}$.) between them is within the experimental error. On October 20, after digitalis $2.3 \mathrm{gm}$. was given, the excursion increased to $6.6 \mathrm{~mm}$., and the T-waves showed slight changes. Digitalis was then discontinued. Eighteen days later, November 7 , the 
excursion of the same portion of the left ventricular margin decreased to $2.9 \mathrm{~mm}$. In order to account for the change in the height of the excursion, aside from the effect produced by digitalis, two other factors must be considered as being possible contributors in bringing it about; first, the rate and second, the blood pressure. That the
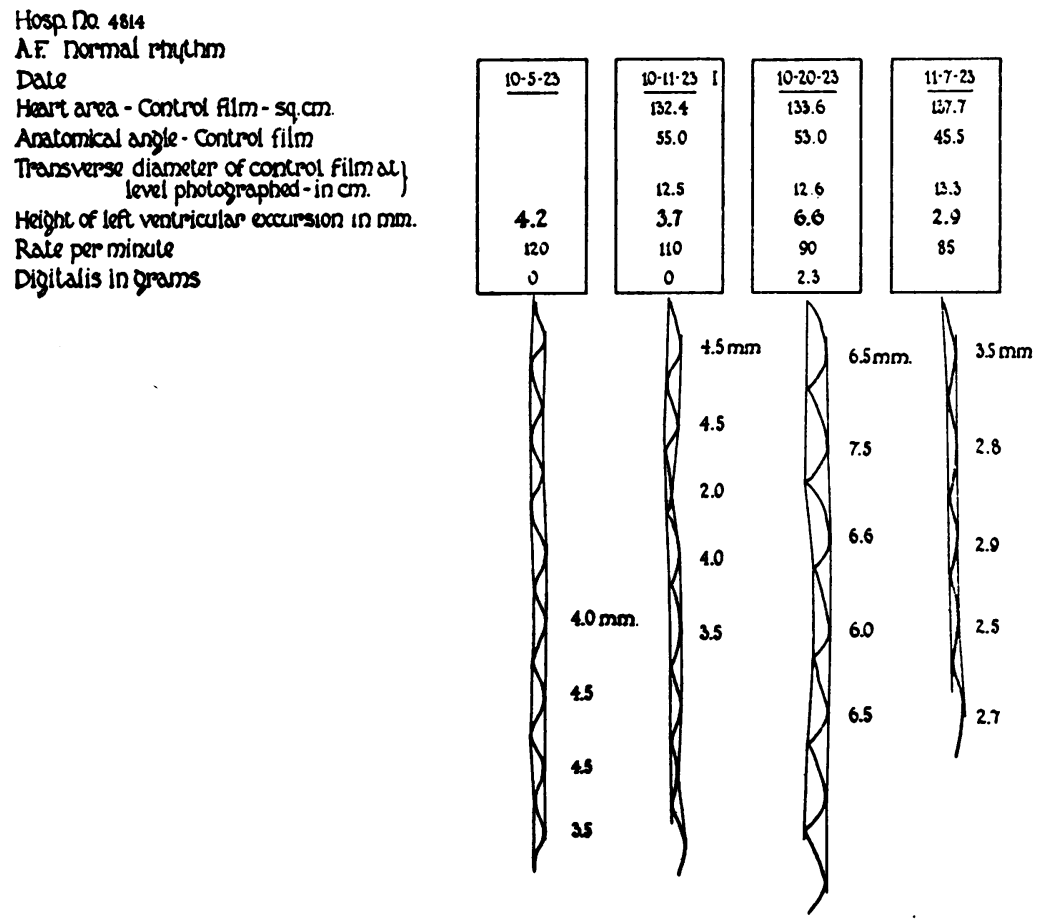

Fig. 6. SEE FIGURE 5

decrease in rate was not a material factor is shown by the fact that on November 17, when the effect of digitalis had worn off the ventricular excursion decreased to $2.9 \mathrm{~mm}$. although the rate was approximately the same ( 85 per minute) as when the excursion was $6.6 \mathrm{~mm}$. Nor, as the records show could changes in the blood pressure, either systolic or diastolic, be associated with the difference found (table 2, fig. 6). 


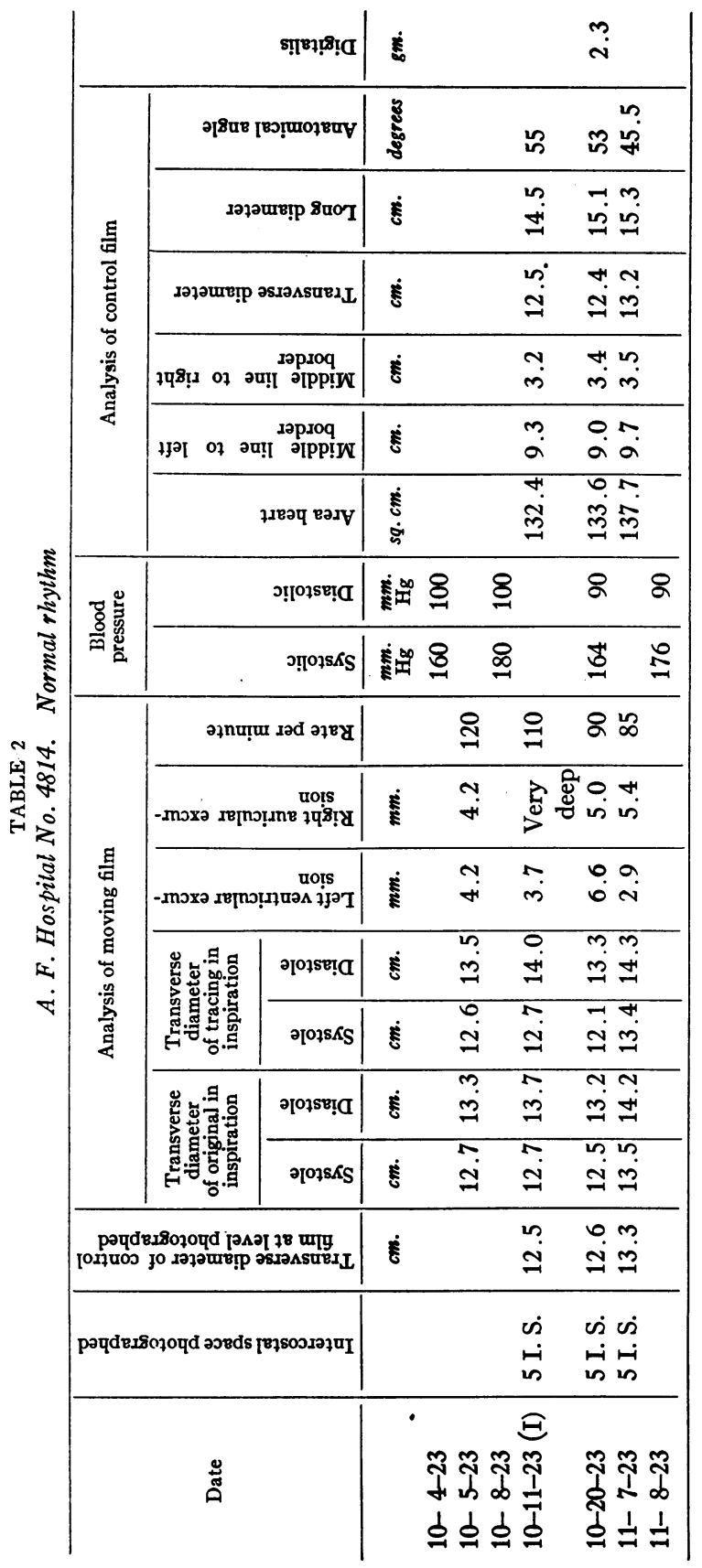


Case 3. T. S., Hosp. No. 4390 , was a male, 24 years old. He complained of cough and shortness of breath. He had rheumatism at 9 years. Four years later there was an attack of shortness of breath while working as a laborer. He was rejected by the Navy in 1917 because of heart trouble, the first intimation the patient had of the presence of this disease. In 1919 the first symptom, shortness of breath, occurred. In 1921 he was first admitted to hospital because of cough, edema and shortness of breath. Since then there have been three breaks in compensation.

On physical examination auricular fibrillation was found to be present. The heart was enlarged. There were the signs of mitral stenosis and insufficiency, and in the electrocardiogram, of right ventricular preponderance. The blood pressure was 90-105 systolic and 50-70 diastolic. The urine was normal.

On November 16, after having received digitalis, the ventricular excursion was $8.5 \mathrm{~mm}$. in the 6 th interspace, the rate being 100 per minute. The effect of this amount of digitalis was allowed to wear off. Then, on December 3, the ventricular excursion decreased to $4.6 \mathrm{~mm}$., the rate being 115 per minute (table 3 , figs. 7 and 8). Between December 3, and December 17, digitalis 5 gms. was given; the ventricular excursion again increased to $8.5 \mathrm{~mm}$., the rate being 90 per minute. Although he continued to receive digitalis the ventricular excursion fell slightly to $8.3 \mathrm{~mm}$. on December 31 . Coincidently there was a slight decrease in rate $(80)$.

On the same days that the photographs were made in the 6 th interspace, a parallel set was taken in the 5th interspace. The excursion at this point was $10.4 \mathrm{~mm}$. on November 16 , then after the digitalis effect had worn off, it decreased to $8.2 \mathrm{~mm}$. (December 3 ), but increased again when the patient was for a second time placed under the influence of digitalis to $12.7 \mathrm{~mm}$. (December 17) and $12.0 \mathrm{~mm}$. (December 31).

A comparison of the series in the 6th and 5 th interspaces shows that difference in the heights of the excursion is found at different portions of the margin, and that in both series the effect of digitalis in increasing the ventricular excursion is equally exhibited. Attention is called in this case of auricular fibrillation to the total irregularity of the rhythm, and to the variation in the height of the excursions. 


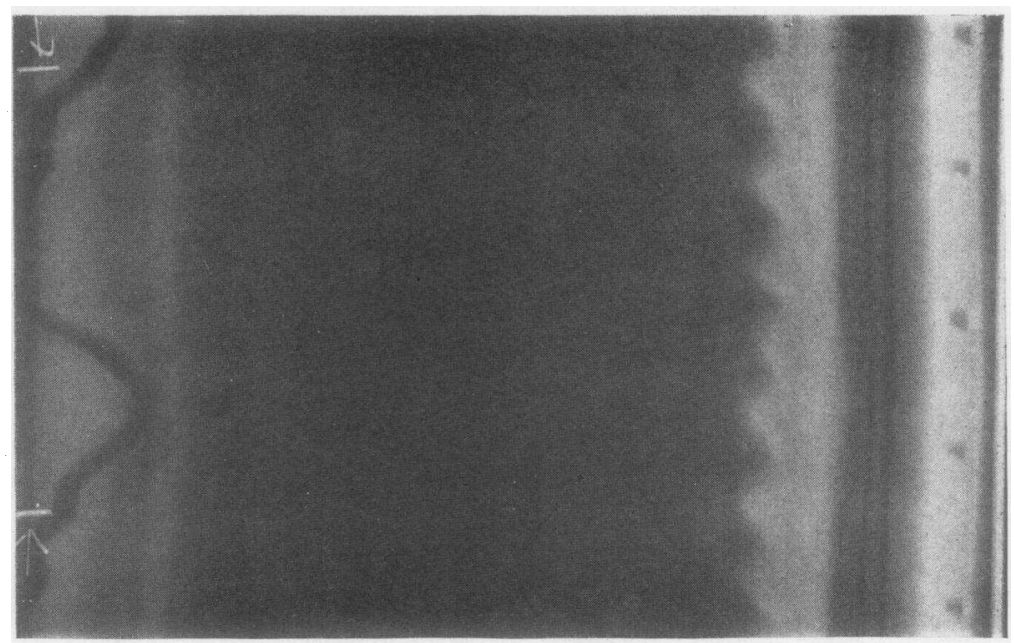

$7 \mathrm{a}$

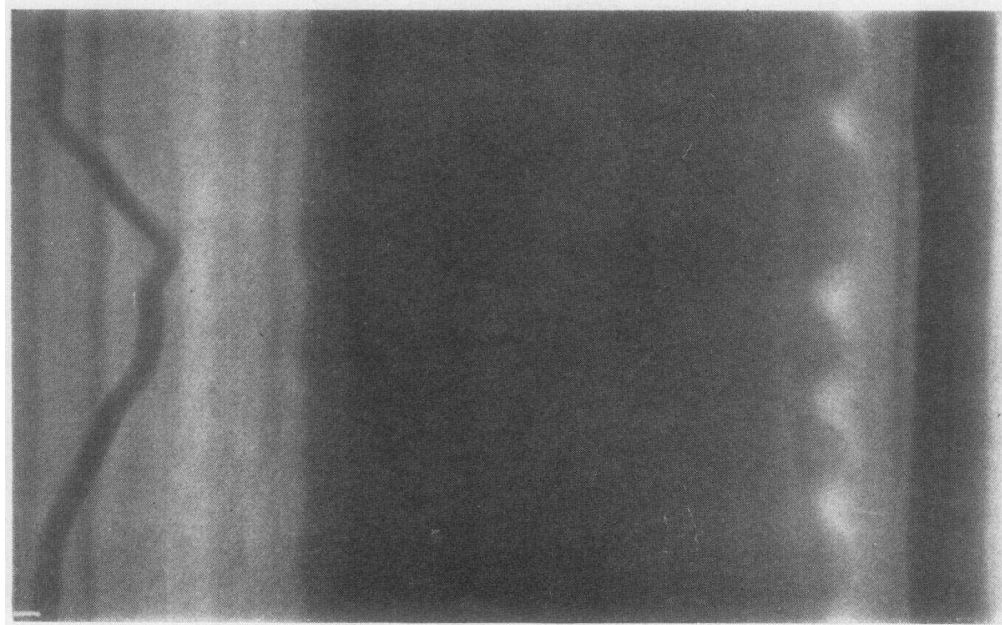

$7 b$

Fig. 7. Moving X-Ray Film

(a) was taken 12-3-23, before and (b) was taken 12-17-23, after the administration of a total of digitalis $5.0 \mathrm{gm}$. 


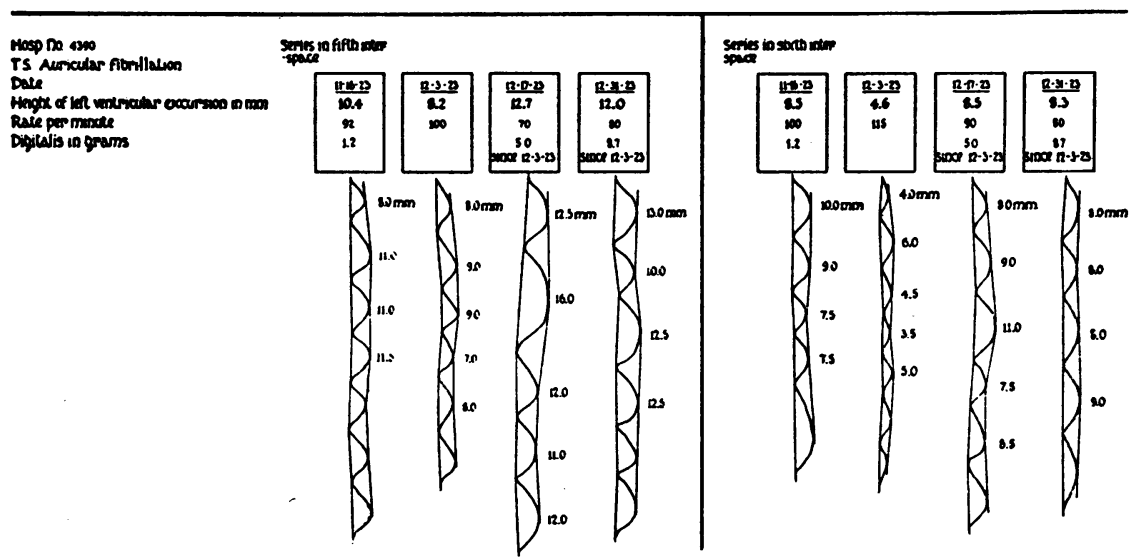

Fig. 8. See Figure 5

TABLE 3

T. S. Hospilal No. 4390. Auricular fibrillation

\begin{tabular}{|c|c|c|c|c|c|c|}
\hline \multirow[b]{2}{*}{ Date } & \multirow{2}{*}{$\begin{array}{l}\text { Intercostal } \\
\text { space } \\
\text { photographed }\end{array}$} & \multicolumn{2}{|c|}{ Analysis of moving film } & \multicolumn{2}{|c|}{ Blood pressure } & \multirow{2}{*}{ Digitalis } \\
\hline & & $\begin{array}{c}\text { Left } \\
\text { ventricular } \\
\text { excursion }\end{array}$ & $\begin{array}{c}\text { Rate per } \\
\text { minute }\end{array}$ & Systolic & Diastolic & \\
\hline & & $m m$. & & $m m . \mathrm{Hg}$ & mm. $\mathrm{Hg}$ & sm. \\
\hline $11-15-23$ & & & & 100 & 60 & \\
\hline $11-16-23$ & 6 I. S. & 8.5 & 100 & & & \\
\hline $12-3-23$ & $6 \mathrm{I} . \mathrm{S}$. & 4.6 & 115 & 93 & 60 & 1.2 \\
\hline $12-17-23$ & $6 \mathrm{I} . \mathrm{S}$. & 8.5 & 90 & 86 & 58 & $5.0^{*}$ \\
\hline $12-31-23$ & 6 I. S. & 8.3 & 80 & 90 & 60 & $8.7^{*}$ \\
\hline $11-15-23$ & & & & 100 & 60 & \\
\hline $11-16-23$ & 5 I. S. & 10.4 & 92 & & & \\
\hline $12-3-23$ & 5 I. S. & 8.2 & 100 & 93 & 60 & 1.2 \\
\hline $12-17-23$ & 5 I. S. & 12.7 & 70 & 86 & 58 & 5.0 \\
\hline $12-31-23$ & 5 I. S. & 12.0 & 80 & 90 & 60 & 8.7 \\
\hline
\end{tabular}

* Since December 3, 1923.

Case 4. M. H., Hosp. No. 4932, was a male, 20 years old. He complained of shortness of breath for 3 months. His illness began suddenly $3 \frac{1}{2}$ months before admission with precordial pain and blood streaked sputum following the severe exertion of lifting packing cases. He continued at work though he had slight cough and saw blood streaked sputum. Gradually dyspnea increased until 3 months ago (October 30) when he had a frank pulmonary hemorrhage which awakened him in the early morning. Bloody sputum continued for several days after this. One month later (December 3) the patient again expectorated bloody sputum. He went to a hospital and was given tincture of digitalis, but did not continue its use intelligently afterward. He did not recall having had rheumatism. 
He suffered from diphtheria at the age of 4, for which he was given antitoxin. He had influenza at $14 \frac{1}{2}$ years.

On physical examination he was found to be suffering from auricular fibrillation. The temperature was $101^{\circ}$ and continued to be slightly elevated for several weeks. It fell while he was taking digitalis. His heart was enlarged and a soft apical systolic murmur was heard. Occasionally a few râles were found on the extreme bases of the lungs after deep breathing. The blood pressure was 90-100 systolic and 60 diastolic. There was no edema. The urine was negative. The Wassermann reaction was negative. The urea index was 99 . The kidney function was normal on the concentration and dilution tests and of the phenolsulphonethalein test (73.8 per cent). Under the influence of digitalis he made satisfactory progress; there was decrease in the ventricular rate, decrease in pulse deficit and alleviation of the symptoms of palpitation and dyspnea.

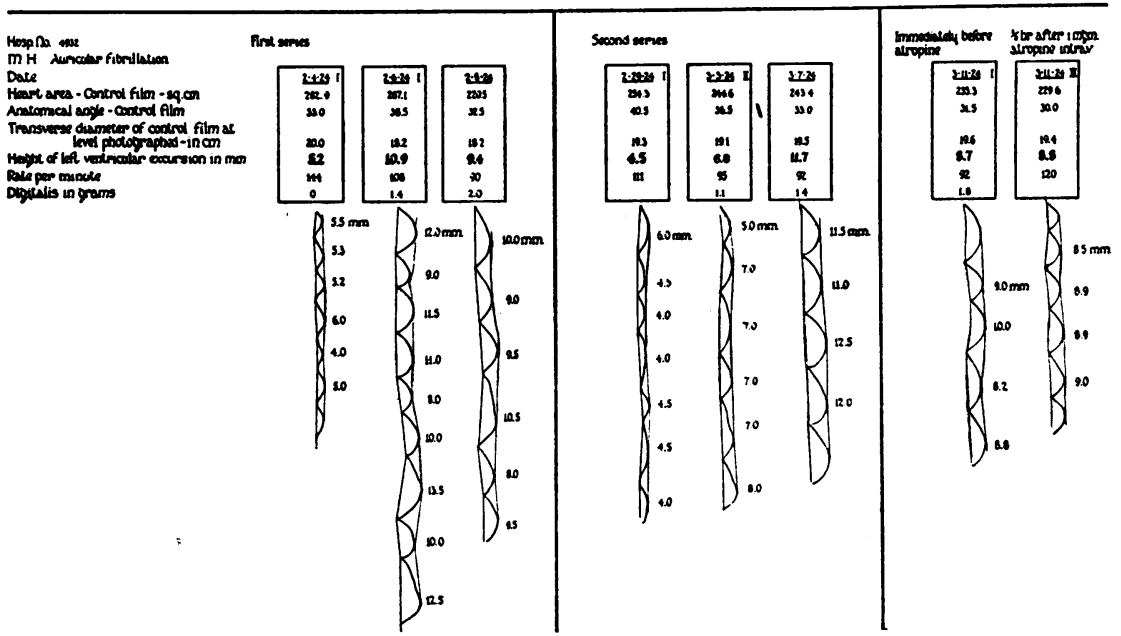

Fig. 9. See Figure 5

On February 4, 1924, the excursion in the 5th interspace was 5.2 mm.; the rate was 144 per minute. Two days later (Feburary 6), after giving digitalis $1.4 \mathrm{gm}$., the excursion increased to $10.9 \mathrm{~mm}$. the rate being 108 per minute (täble 4, fig. 9). On February 8, after a total of digitalis $2.0 \mathrm{gm}$. had been administered the height of the excursion fell slightly to $9.4 \mathrm{~mm}$; the rate was 90 per minute. The patient was given no more digitalis for 3 weeks; in the meantime the effect of the drug wore off. A second set of observations was then made. On February 29 (I), the excursion had fallen to $4.5 \mathrm{~mm}$.; the rate being 111 per minute. On March 3 (II) after digitalis 1.1 
gm. was given, the excursion increased to $6.8 \mathrm{~mm}$; the rate being 95 per minute; and on March 7, after having taken digitalis $1.4 \mathrm{gm}$., it rose still farther to $11.7 \mathrm{~mm}$., and the rate decreased slightly to 92 per minute.

In this patient, the effect of the ventricular rate on the extent of excursion was studied in greater detail. On February 4, when the rate was 144 per minute and on February 29, when it was 111, the patient was without digitalis; the ventricular excursions were 5.2 and $4.5 \mathrm{~mm}$. respectively. After giving digitalis the height of the excursion rose to $10.9 \mathrm{~mm}$. in the first series and to $11.7 \mathrm{~mm}$. in the second. The following test was then carried out on March 11; the height of the excursion was $8.7 \mathrm{~mm}$. and the rate, 92 per minute, the patient still being under the influence of digitalis. Immediately after this curve was taken the patient was given atropine $1 \mathrm{mgm}$. intravenously; one half hour after the injection a moving film was again taken and the ventricular excursion measured $8.8 \mathrm{~mm}$., the ventricular rate having now risen to 120 per minute. Although the heart rate increased 30 per cent, the height of the ventricular excursion remained unchanged.

The increase in rate did not influence the height of the excursion. It is of course not intended to infer that this statement applies in general. It applies only when digitalis has been administered. It is necessary that one of the two factors to be tested should remain constant.

This patient alone in the series showed a significant change in the size of the heart under the influence of digitalis. The decrease took place on the left side of the heart (table 4).

In order to show that the method is valid, the following measurements of a control normal individual (W. LaR.) over one year are given (table 5). On March 26, 1923, the left ventricular excursion measured $8 \mathrm{~mm}$. in the 4 th interspace, the cardiac rate being 60 per minute. Ten days later the ventricular excursion measured $7.2 \mathrm{~mm}$.; and one year later, $8.1 \mathrm{~mm}$., the heart rate remaining unchanged. These figures show a surprising constancy; they demonstrate the fact that comparable curves are obtainable not only over short, but also over long periods of time. Analysis of the control films showed that identical points on the left ventricular border had been photographed 


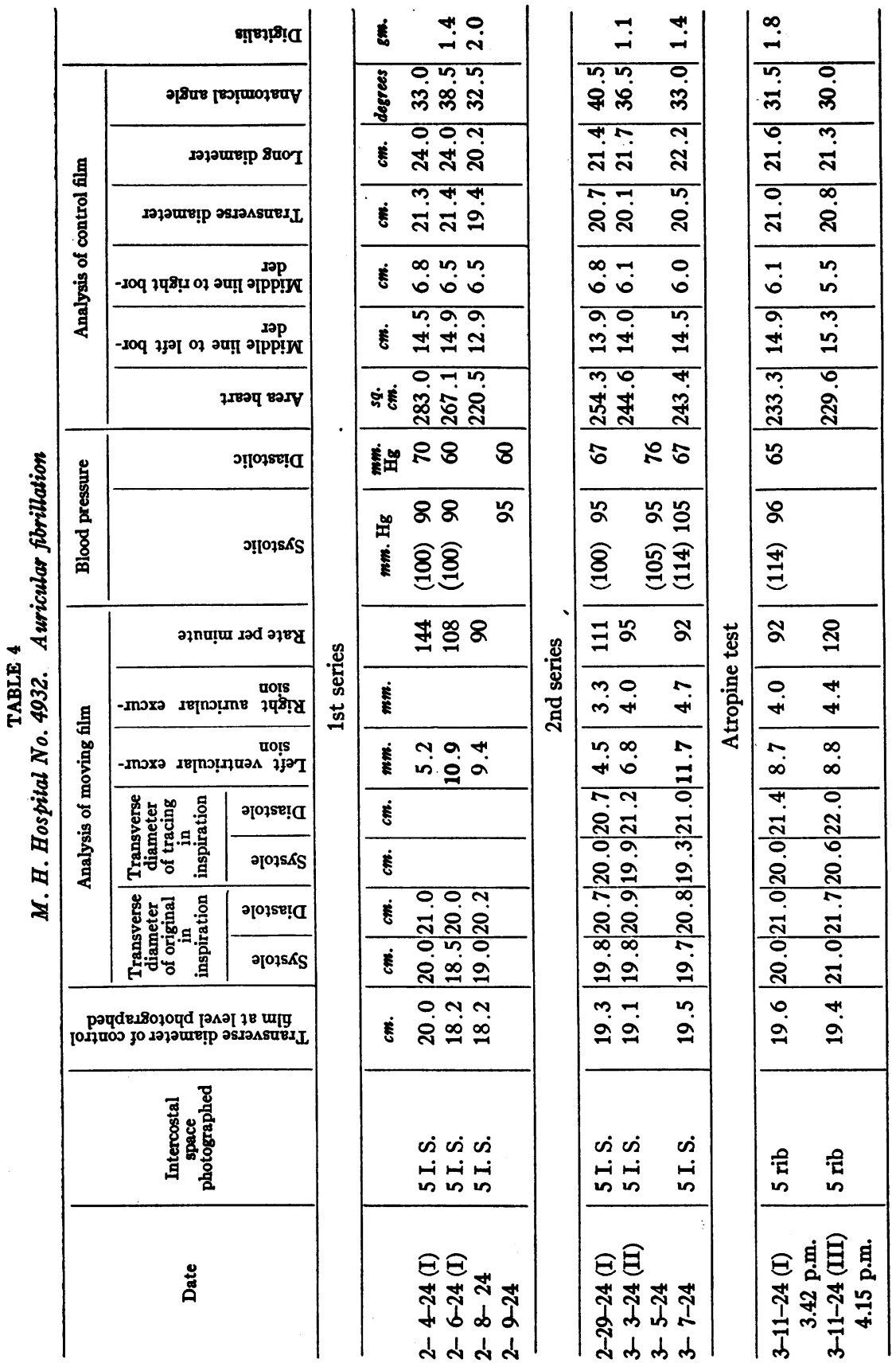




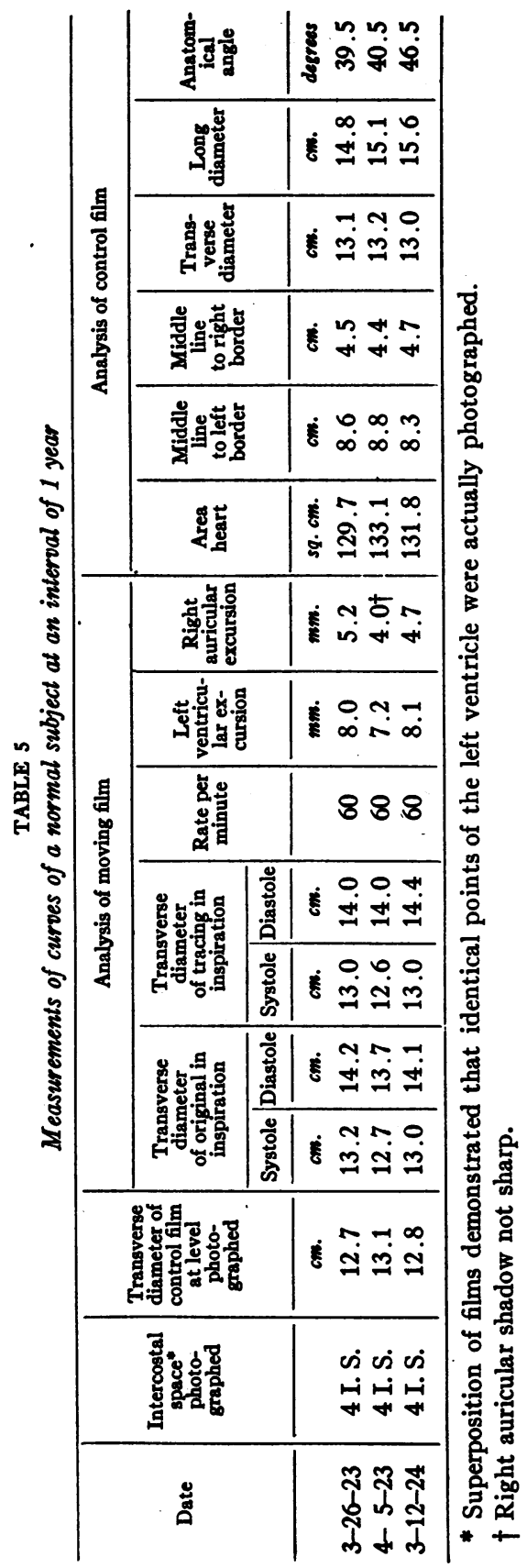


on the moving film and that the heart kad not changed in size during the period of the observation.

\section{DISCUSSION}

What part slowing the heart rate mayplay in increasing the ventricular excursion after giving digitalis has already been indicated. It has been shown that for the rates within the range we met in our observations this factor is negligible. Beyond certain narrow limits however other influences obviously come into play, and may naturally be expected to change the height of the excursion. What effect change in the height of the blood pressure may have on the extent of the ventricular excursions remains to be discussed.

It was discovered in 1839 by Blake that giving digitalis to animals under experimental conditions causes an elevation of blood pressure. This effect is now well known. In more recent years Gottlieb $(1901,1902)$ and his co-workers have associated this effect with constriction of the blood vessels, due to a direct action of digitalis on the vessel walls. However this may be, the problem of its action in man is concerned not so much with local effects on the vessels in distant viscera, such as the kidneys and intestines, which have been studied by Jonescu and Loewi (1908), Kasztan (1910), Hedinger, (1912) Naegele, (1911) Fahrenkamp (1911) and Joseph (1913), as with the effect on aortic pressure which results from this action. For it is against aortic pressure that the heart must work. Joseph (1913) states that in rabbits it requires only $28 \mathrm{mg}$. per kilo to increase contraction 12 per cent, but $50 \mathrm{mg}$. to bring about even a slight rise in blood pressure. Experiments dealing with this phase of the matter have recently been carried on by de Heer (1912), Straub (1914), Patterson, Piper and Starling (1914), and Wiggers and Katz (1922). Their experiments have shown that, although the systolic and diastolic cardiac volumes are both increased by raising the resistence offered by the aorta, the extent of the excursion in contraction is unchanged until the resistance to be overcome passes a certain limit; and then there is a decrease in the height of the excursion. Even if giving digitalis raises the aortic pressure, it is unnecessary therefore to expect, in the light of these experiments, a change in the excursion of the ventricular wall. In the case of our observations, the diastolic 
volumes, measured in terms of the transverse diameter and the areas of the cardiac silhouette, did not even change; in one case, indeed, they actually decreased.

It was usually believed on the basis of experiments in pharmacology, before 1900, when taking the blood pressure in human beings was still uncommon, that giving digitalis raised the pressure. This belief was gradually abandoned after the statements on this subject by Gottlieb and Sahli (1901). Since the more extended observations by Mackenzie (1911), Cushny (1911), Cohn (1917), Robinson (1920), Eggleston (1917) and Luten (1924) the fact is now established that no change in the systolic blood pressure takes place under the influence of digitalis, while the diastolic pressure, unless heart failure is present, often falls. When heart failure is present the elevated systolic pressure usually falls as well.

In the four patients included in this study, no definite changes in the resting blood pressure levels were observed, when they were under the influence of digitalis. The systolic level remained unchanged four times (Case 1; Case 3, twice; Case 4); decreased $16 \mathrm{~mm}$. $\mathrm{Hg}$ once (Case 2); and increased $10 \mathrm{~mm}$. $\mathrm{Hg}$ once (Case 4). The diastolic level was unchanged three times (Case 1; Case 4; Case 3); and decreased $10 \mathrm{~mm}$. Hg twice (Case 4; Case 2). In none of the observations was a rise in the diastolic pressure seen.

There were seen, in short, no significant or consistent changes in either the systolic or diastolic blood pressure. The changes in the excursion of the ventricle which we saw, were, therefore, not influenced by this as an important factor. Nor are the slight changes, assuming that they took place, of such a nature as to be able to bring about the effects we noticed.

\section{SUMMARY}

The effect of digitalis in therapeutic doses was studied in patients by the method of the moving x-ray film. Four patients were studied in this manner. Two of these exhibited a normal rhythm and the other two that of auricular fibrillation. In all cases a significant increase in the height of the left ventricular excursion was seen when the patients were under the influence of digitalis. As the effect of the drug wore off the height of the excursion decreased. As a rule 
no decrease in the size of the heart took place. We believe that this is the first time that the effect of a drug upon the contraction of heart muscle in man has been studied directly.

\section{BIBLIOGRAPHY}

Aran, F. A. Phila., 1843. Practical Manual of the Diseases of the Heart and Great Vessels. Trans. from the French by Wm. A. Harris.

Balfour, G. W. London, 1898, 3rd edition (1st edition-1875). Clinical Lecture on Diseases of the Heart and Aorta.

Bardeen, C. R. Amer. Jour. Anat., 1918, xxiii, 423. Determination of the Size of the Heart by Means of the X-rays.

Becker, Th. Deut. Arch. f. klin. Med., 1914, cxiii, 216. Die Analyse des Elektrokardiogrammes mittels der Röntgenkymographie.

Beddoes, T. London, 1801. Observations on the Medical and Domestic Management of the Consumptive; on the Powers and Agency of Digitalis; etc.

Bertin, R. J., and Bouillaud, J. Paris, 1824. Traité des maladies du coeur.

Blake, J. Edinburgh Medical and Surgical Journal, 1839, li, 330-345. Observations on the Physiological Effects of Various Agents Introduced into the Circulation, as Indicated by the Haemadynamometer.

Boehm, R. Arch. ges. Physiol., 1872, v, 164. Untersuchungen uber die physiologische Wirkung der Digitalis und des Digitalein.

Bramwell, B. Edinburgh. 1884. Diseases of the Heart and Thoracic Aorta.

Cohn, A. E. (1915 a) Jour. Amer. Med. Assn., lxv, 1527. Clinical and Electrocardiographic Studies on the Action of Digitalis.

Cohn A. E. (1915 b) with Fraser, F. R., and Jamieson, R. A. Jour. Exper. Med., xxi, 593. The Influence of Digitalis on the T-wave of the Human Electrocardiogram.

Cohn, A. E. Med. Clin. of N. America, 1917, i, 563. The Clinical Pharmacology of Digitalis.

Corrigan, D. J. Edin. Med. and Surg. Jour., 1832, xxxvii, 225. Insufficiency of the Aortic Valve.

Corvisart, J. N. Paris, 1811. Essai sur les maladies et les lésions organiques du coeur et des gros vaisseaux.

Crane, A. W. Amer. Jour. Ront., 1916, iii, N. S., 513. Rontgenology of the Heart.

Cushny, A. R. Jour. Exper. Med., 1897, ii, 233. The Action of Substances of The Digitalis Series on the Circulation in Mammals.

Cushny, A. R. Amer. Jour. Med. Sci., 1911, cxli, 469. The Therapeutics of Digitalis and Its Allies.

de Heer, J. L. Pflügers Arch. f. d. ges. Physiol., 1912, cxlviii, 1. Die Dynamik des Saugetierherzens im Kreislauf in der Norm, bei Aortenstenose und nach Strophanthin. 
Dessauer, F. Zentralbl. f. Herz- u Gefassenkrankheiten. 1912, iv, 349. Weitere Arbeiten auf dem Gebeite der Blitzlightaufnahmen und der Rontgen-Kinematographie.

Eggleston, C. Jour. Amer. Med. Assn., 1917, lxix, 951. The Influence of Large Doses of Digitalis and Digitoxin on the Blood Pressure in Man.

Einhorn, H. Sammlung kl. Vorträge, 1901, Nr.312, 511. Ueber die Anwendung der Digitalis bei Erkrankungen des Herzens.

Eychmüller, H. Berl. klin. Wchnschr., 1909, xlvi, 1677. Ueber die Herz- und Gefässwirkung des Digalens bei gesunden und kranken Menschen.

Eyster, J. A. E., and Meek, W. J. Amer. Jour. Ront., 1920, vii, 471. Instantaneous Radiographs of the Human Heart at Determined Points in the Cardiac Circle.

Fahrenkamp, C. Arch. f. exper. Pathol. u. Pharmakol., 1911, lxv, 367. Uber die verschiedene Beeinflussung der Gefässgebiete durch Digitoxin.

Ferriar, J. Manchester, 1799. An Essay on the Medical Properties of Digitalis Purpurea or Foxglove.

Fothergill, J. M. London and Philadelphia, 1871. Digitalin, Its Mode of Action and Its Use.

Fraenkel, A. Charité-Annalen., 1882, vii, 351. Zur Lehre von der Wirkung grosser Digitalisdosen im Zeitraum der wiederholten Compensationsstörung bei Herzklaffenfehlern.

Gibson, G. A. Edinburgh, 1898. Diseases of the Heart and Aorta.

Gött, Th., und Rosenthal, J. Munch. med. Wchnschr., 1912, lix, 2033. Ueber ein Verfahren zur Darstellung der Herzbewegungen mittelst Rontgenstraklen (Rontgenkymographie).

Gött, Th. Munchen, 1913. Studien uber die Pulsation des Herzens mit Hilfe der Rontgenstrahlen.

Gottlieb, R. Cong. f. Innere. Med., 1901, xix, 21. Herzmittel u. Vasomotorenmittel.

Gottlieb, R., u. Magnus, R. Arch. f. exper. Pathol. u. Pharmakol., 1902, xlvii, 135. Uber die Gefässwirkung der Körper der Digitalisgruppe.

Groedel, F. M. Deut. med. Wchnschr., 1909, xxxv, 434. Die Tecknik der Rontgen-Kinematographie.

Hedinger, M. Munch. med. Wchnschr., 1912, lix, 1098. Ueber die Wirkungsweise von Nieren und Herzmitteln bei nieren Kranken Menschen.

Hope, J. London, 1839. Treatise on the Diseases of the Heart and Great Vessels. 3rd ed.

Jonescu, D., and Loewi, O. Arch. f. exper. Pathol. u. Pharmakol., 1908, lix, 71. Uber eine spezifische Nierenwirkung der Digitaliskorper.

Joseph, D. R. Arch. f. exper. Pathol. u. Pharmakol., 1913, lxxiii, 81. Untersuchungen über die Herz- und Gefässwirkungen kleiner Digitalisgaben bei intravenöser Injektion. 
Jürgensen, Th. v. Wien, 1899. Nothnagels Handbuch. Vol. xv, part 1, p. 75. Insuffizienz (Schwäche) des Herzens.

Kasztan, M. Arch. f. exper. Path. u. Pharmakol, 1910, lxiii, 406. Beiträge zur Kenntnis der Gefässwirkung des Strophanthins.

Kinglake, R. London, 1801. (In Beddoes, T. Observations on the Medical and Domestic Management of Consumptive, etc.) Cases and Observations on the Medical Efficacy of Digitalis Purpurea in Phthisis Pulmonalis, with Speculations on Its Modus Operandi, and on Analogous Remedies.

Krehl, L. Nothnagels spez. Path. u. Therap., Wien., 1901. Die Erkrankungen des Herzmuskels.

Kreysig, F. L. Die Krankheiten des Herzens systematisch bearbeitet und durch eigene beobachungen erläutert. Berlin 1816. Zweiter Theil, Zweite Abtheilung, welche die Erkenntniss und Behandlung der besondern organischen und mechanischen Krankheiten des Herzens Enthält. VI. Die Blatter des rothen Fingerhutes (pp. 715-728).

Latham, P. M. Leipzig, 1847. Vorlesungen über Herzkrankheiten.

Lewis, T., Drury A. N., and Iliescu, C. C. Heart, 1922, ix, 21. Some Observations upon Atropin and Strophanthin.

Leyden, E. Deut. med. Wchnschr., 1881, vii, 345. Uber die Wirkungsweise und die Indikationen der Digitalis.

Luten, D. Arch. Int. Med., 1924, xxxiii, 251. Clinical Studies of Digitalis. 1. Effects Produced by the Administration of Massive Dosage to Patients with Normal Mechanism.

Mackenzie, J. Brit. Med. Jour., 1905, i, 759. New Method of Studying Affections of the Heart. IV. Action of Digitalis on the Human Heart in Cases when the Inception of the Rhythm of the Heart is Due to the Ventricles.

Mackenzie, J. London, 1913, 3rd edition, p. 377. Diseases of the Heart.

Mackenzie, J. Heart, 1911, ii, 273. Digitalis.

Meyer, A. W. Jena, 1912. Die Digitalistherapie-ihre Indikationen und Kontraindikationen.

Naegele, F. Zentralbl. f. Herz, etc., 1911, iii, 263. Ueber die Gefasswirkung der Digitaliskörper bei gesunden und kranken Menschen.

Nothnagel, C. W. H., and Rossbach, M. J. Handbuch der Arzneimittellehre Siebente Auflage. Berlin, 1894, 841.

Patterson, S. W., Piper, H., and Starling, E. H. Jour. Physiol., 1914, xlviii, 465. The Regulation of the Heart Beat.

Robinson, G. C. Medicine, 1922, i, 1. The Therapeutic Use of Digitalis.

Robinson, G. C. Southern Med. Jour., 1920, xiii, 396. The Value of Large Single Doses of Digitalis in the Treatment of Heart Disease.

Romberg, E. Lehrbuch der Krankheiten des Herzens und der Blutgefässe. Stuttgart, 1906. I. Auflage in Ebstein-Schwalbe, Handbuch der praktischen Medizin, 1899. 
Roy, C. S., and Adami, J. G. Phil Trans. Royal Soc. (London), 1892, clxxxiii, 199. Contributions to the Physiology and Pathology of the Mammalian Heart. Sahli, H. Kongress f. inn. Med., Berlin, 1901, xix, 45. Über Herzmittel und Vasomotorenmittel.

Schmiedeberg, O. Ueber die "Digitalinwirkung" am Herzmuskel des Frosches. Beiträge zur Anatomie und Physiologie als Festgabe Carl Ludwig, zum 15. October, 1874, gewidinet von seinem Schülern. Leipzig, 1874, pt. 1, pp. ccxxii-ccxxviii.

Schoenlein, J. L. Klinische vorträge in den charite-Krankenhause zu Berlin. Berlin, 1842, xii, 179.

Stokes, Wm. Dublin, 1853. The Diseases of the Heart and the Aorta.

Straub, H. Deut. Arch. f. klin. Med., 1914, cxv, 531. Dynamik des Saugetierherzens.

Traube, L. Gesammelte Beiträge zur Pathologie und Physiologie. Berlin, 1871, i, 252. Ueber die Veränderungen welche die Spannung des Arotensystems unter dem Einfluss der Digitalis erleidet.

Vagt, O. Med. klin., 1909, v, 1858-1861, 1895-1897, 1938-1940. Ueber die Herz- und Gefasswirkung des Strophanthins bei gesunden und kranken Menschen.

Walshe, W. H. London, 1854. The Diseases of the Lungs, Heart and Aorta.

Wiggers, C. J., and Katz, L. N. Amer. Jour. Physiol., 1922, lviii, 439. The Contour of the Ventricular Volume Curves under Different Conditions.

Withering, W. Birmingham, 1785. An Account of Foxglove and Some of Its Medical Uses, with Practical Remarks on Dropsy and Other Diseases. 